\title{
Plasma levels of thiocyanate in the Czech population and their genetic determination*
}

\author{
Jaroslav A. Hubáček******, Jan Pitha*, \\ Zdena Škodová**, Věra Lánská***, Rudolf Poledne*,**** \\ *Center for Experimental Medicine, Laboratory of Molecular Genetics, \\ **Department of Preventive Cardiology, ${ }^{* * *}$ Department of Statistics, Institute for Clinical and Experimental Medicine, \\ *****Cardiovascular Research Center, Prague, Czech Republic
}

Hubáček JA*,***, Pitha $\mathrm{J}^{*}$, Škodová $\mathrm{Z}^{* *}$, Lánská $\mathrm{V}^{* * *}$, Poledne $\mathrm{R}^{*, * * * *}$ (*Center for Experimental Medicine, Laboratory of Molecular Genetics, **Department of Preventive Cardiology, ${ }^{* * *}$ Department of Statistics, Institute for Clinical and Experimental Medicine, ${ }^{* * * *}$ Cardiovascular Research Center, Prague, Czech Republic. Plasma levels of thiocyanate in the Czech population and their genetic determination. Cor Vasa 2006;48(7-8):262-266.

Background: Plasma thiocyanate levels are a commonly used marker for smoking status determination. It is not known whether there is any genetic predisposition in terms of plasma thiocyanate levels. We have evaluated possible genetic predetermination of plasma thiocyanate levels in a population-based study.

Material/methods: In 131 men and 154 women, the plasma levels of thiocyanate were detected photometrically after reaction with $\mathrm{Fe}\left(\mathrm{NO}_{3}\right)_{3}$. Twenty-three genetic markers on 8 chromosomes were analyzed by PCR.

Results: The plasma levels of thiocyanate were significantly $(p<0.01)$ higher in smokers compared to non-smokers and in males $(p<0.01)$ compared to females.

The effects of genetic markers at positions 11q23 $(p<0.05)$ and 19q13.1 $(p<0.01)$ on plasma thiocyanate levels were determined in both males and females in independent analyses. Other variants exhibited no significant effect on the plasma levels of thiocyanate.

Conclusion: The plasma levels of thiocyanate are higher in males than in females and in smokers than in non-smokers. Out of the 23 analyzed genetic variants, two are associated with plasma levels of thiocyanate. The plasma levels of thiocyanate are not likely to be a genetically independent marker for smoking/non-smoking status.

Key words: Smoking - Polymorphisms - Thiocyanate

Hubáček JA*****, Pitha $J^{*}$, Škodová $Z^{* *}$, Lánská $\mathrm{V}^{* * *}$, Poledne $\mathrm{R}^{*, * * * * *}$ (*Pracoviště experimentální medicíny, Laboratoř molekulární genetiky, **Pracoviště preventivní kardiologie, ***Statistické oddělení, Institut klinické a experimentální medicíny, ****Centrum pro výzkum chorob srdce a cév, Praha, Česká republika. Plazmatické koncentrace thiokyanátu u české populace a jejich genetická determinace. Cor Vasa 2006;48(7-8):262-266.

Kontext: Plazmatické koncentrace thiokyanátu jsou často užívaným ukazatelem při stanovení kuřáctví. Není známo, zda z hlediska plazmatických koncentrací existuje genetická predispozice. V populační studii jsme hodnotili možnost genetické predeterminace plazmatických koncentrací thiokyanátu.

Materiál/metody: Plazmatické koncentrace thiokyanátu byly stanoveny fotometricky po reakci s $\mathrm{Fe}\left(\mathrm{NO}_{3}\right)_{3}$ u 131 mužů a 154 žen. Metodou PCR bylo určeno 23 genetických markerů na 8 chromozomech.

Výsledky: Plazmatické koncentrace thiokyanátu byly statisticky významně $(p<0,01)$ vyšší u kuřáků ve srovnání s nekuřáky i u mužů $(p<0,01)$ ve srovnání s ženami.

Vliv genetických markerů na pozicích 11q23 $(p<0,05)$ a 19q13.1 $(p<0,01)$ na plazmatické koncentrace thiokyanátu byly nalezeny u mužů a u žen v samostatných analýzách. Další varianty nevykazovaly na plazmatické koncentrace thiokyanátu významný vliv.

Závěr: Plazmatické koncentrace thiokyanátu jsou u mužů a kuřáků vyšší než u žen a nekuřáků. Z 23 hodnocených genetických variant souvisí s plazmatickými koncentracemi thiokyanátu dvě. Není pravděpodobné, že by plazmatické koncentrace thiokyanátu byly geneticky nezávislým ukazatelem kuřáctví/nekuřáctví.

Klíčová slova: Kuřáctví - Polymorfismus - Thiokyanát

Address: Ing. J. A. Hubáček, Center for Experimental Medicine, Laboratory of Molecular Genetics, IKEM, Vídeňská 1958/9, 14021 Prague 4, Czech Republic, e-mail: jahb@medicon.cz

*This work was partially supported by Institute for Clinical and Experimental Medicine (MZO 00023001). 


\section{INTRODUCTION}

Smoking is known to be one of the most important risk factors for premature death worldwide. It is estimated that, in the 1990's, smoking was responsible for 30\% of deaths in the age group between 35 and 69 years, most of them from coronary artery disease. Despite intensive antismoking campaigns, approx. 30\% of adults in various populations continue to smoke. ${ }^{(1)}$

Biochemical evidence of smoking status is usually obtained using the analysis of plasma levels of thiocyanate. In the body, thiocyanate is produced from cyanate, a substance present in tobacco smoke. The plasma levels of thiocyanate are significantly higher in smokers compared to non-smokers, and it is suggested that the levels may also correlate with the number of cigarettes smoked. The half-life of plasma thiocyanate is two weeks. Unfortunately, this parameter is not unmistakably specific, because plasma thiocyanate levels are influenced by an increased intake of some vegetables and by contact of the individual being examined with industrial cyanide-containing chemicals. ${ }^{(2)}$

Just as with all known biochemically determined parameters, one must assume that the final plasma levels of thiocyanate are the result of the combined effect of environmental (smoking, exposure to industrial chemicals) and genetic factors.

Genetic predisposition, which could possibly affect the plasma levels of thiocyanate, has not yet been analyzed, and it is not clear which variants in which genes could be responsible for some heredity in plasma thiocyanate levels.

Initial analysis of genetic determination of any parameter is usually made using variable number of tandem repeat polymorphisms-like markers. These polymorphisms are characterized by high numbers of alleles, and are analyzed in populations or pedigrees, where one specific allele is associated with the transmission of the analyzed parameter from the first to the second generation or, for example, is found more frequently in a group with high or low levels of the analyzed parameter.

Although they will have a slightly lower information power, single nucleotide polymorphisms (SNP) could also be used in a similar way. In our study, we compared the plasma levels of thiocyanate with all SNPs, which had been analyzed in one population sample in many studies with different designs.

Twenty-three SNPs on 14 genes localized on 8 different chromosomes were analyzed. All SNPs have been analyzed in studies with different designs previously and we used them just like markers for characterization of the chromosome parts. The following genes were analyzed (chromosomal localizations are shown in parentheses, information about chromosomal localizations is from OMIM database, http://www.ncbi.nlm.nih.gov/omim/): genes for apolipoprotein (APO) B (2p24), APOCI (19q13.2), APOCIII (11q23), and APOE (19q13.2), genes for bactericidal/permeability increasing protein (20q11.23-q12), and lipopolysaccharide-binding protein (20q11.23-q12), genes for the CD14 receptor (5q31.1), lipoprotein lipase (8p22), hepatic lipase (15q21-q23), transforming-growth factor $\beta 1$ (19q13.1), cholesterol 7 alpha hydroxylase (8q11-q12), angiotensin-converting enzyme (17q23) and ABC transporters G5 and G8 (2p21).

We measured the plasma levels of thiocyanate in a Czech Caucasian population and analyzed if there are some sex differences. Additionally, the effects of smoking and menopausal status were analyzed. Associations among individual genetic markers and the plasma levels of thiocyanate were analyzed in an effort to identify positions on chromosomes, which could be responsible for genetic determination of the plasma levels of thiocyanate.

\section{PARTICIPANTS AND MEASUREMENTS}

The 285 unrelated individuals (131 men and 154 women, respondence rate $70 \%$ ) included in this study represented an 8-year cohort of a $1 \%$ representative Czech population sample selected under the protocol of the WHO-sponsored MONICA study ${ }^{(3)}$ in 1988 when aged 25-64 years and re-examined in 1996. Written informed consent was obtained from the study participants; the study design was approved by the local ethics committee.

Three $\mathrm{ml}$ of blood collected into EDTA tubes for DNA isolation was diluted with sterile water at a $1: 1$ ratio and stored at $-20^{\circ} \mathrm{C}$. DNA was isolated by standard method.(4) Analyses of genetic polymorphisms in the APOE, ${ }^{(5)}$ APOCI, ${ }^{(6)}$ APOCIII, ${ }^{(6)}$ APOB, ${ }^{(7)}$ TGF $\beta-1,{ }^{(8)}$ hepatic lipase ${ }^{(9)}$ and lipoprotein lipase, ${ }^{(9)}$ lipopolysaccharide-binding protein, ${ }^{(10)}$ bactericidal/permeability increasing protein, ${ }^{(10)}$ ABCG5 and ABCG8 transporters, ${ }^{(11)}$ cholesterol $7-\alpha$ hydroxylase, ${ }^{(12)}$ CD14 receptor, ${ }^{(13)}$ and $\mathrm{ACE}^{(14,15)}$ were performed using PCR with subsequent restriction of the PCR products (does not apply to APOB and ACE polymorphisms) using appropriate restriction enzymes as described previously.

Restriction fragments were analyzed by a $7.5 \%$ polyacrylamide MADGE gel system, ${ }^{(16)} 2 \%$ agarose gel (APOCI polymorphism), or by $12 \%$ vertical polyacrylamide electrophoresis (APOE and TGF $\beta-1$ polymorphisms).

Plasma levels of thiocyanate were determined photometrically after reaction with $\mathrm{Fe}\left(\mathrm{NO}_{3}\right)_{3}$.

ANOVA was used for statistical analysis. In cases where there were fewer than five rare homozygote

Table I

Basic characteristics of the population (values are given as mean $\pm \mathrm{SD}$ )

\begin{tabular}{lcc}
\hline \hline & Males & Females \\
\hline $\mathrm{N}$ & 131 & 154 \\
Age (years) & $55.4 \pm 11.6$ & $55.5 \pm 11.2$ \\
$\mathrm{BMI}\left(\mathrm{kg} / \mathrm{m}^{2}\right)$ & $28.40 \pm 4.07$ & $29.09 \pm 5.73$ \\
Smoking prevalence $(\mathrm{N} / \%)$ & $48 / 36.6$ & $28 / 18.2$ \\
Number of cigarettes per & $105 \pm 56$ & $77 \pm 42$ \\
week (in smokers) & & \\
Thiocyanate $(\mu \mathrm{mol} / \mathrm{l})$ & $106 \pm 54$ & $134 \pm 45$ \\
Thiocyanate $(\mu \mathrm{mol} / \mathrm{l})$ & $132 \pm 48$ & $74 \pm 37$ \\
- smokers & & \\
Thiocyanate $(\mu \mathrm{mol} / \mathrm{l})$ & $90 \pm 59$ & \\
- non-smokers & & \\
\hline \hline
\end{tabular}

BMI - body mass index 
Table II

Alleles and genotypes frequencies of the individual SNPs

\begin{tabular}{|c|c|c|c|c|c|c|}
\hline Polymorphism & Chromosome & 11 & 12 & 22 & & \\
\hline $\begin{array}{l}\text { ABCG8 } \\
\text { Asp19His }\end{array}$ & $2 \mathrm{p} 21$ & $\begin{array}{l}2 \\
(0.7)\end{array}$ & $\begin{array}{l}34 \\
(11.9)\end{array}$ & $\begin{array}{l}249 \\
(87.4)\end{array}$ & $\begin{array}{l}\text { 1- His } \\
\text { 2- Asp }\end{array}$ & $\begin{array}{c}38(6.7 \%) \\
532(93.3 \%)\end{array}$ \\
\hline $\begin{array}{l}\text { ABCG8 } \\
\text { Tyr54Cys }\end{array}$ & $2 \mathrm{p} 21$ & $\begin{array}{l}97 \\
(34.0)\end{array}$ & $\begin{array}{l}130 \\
(45.6)\end{array}$ & $\begin{array}{l}58 \\
(20.4)\end{array}$ & $\begin{array}{l}\text { 1- Tyr } \\
2-\text { Cys }\end{array}$ & $\begin{array}{l}324(56.8 \%) \\
246(43.2 \%)\end{array}$ \\
\hline $\begin{array}{l}\text { ABCG8 } \\
\text { Thr400Lys }\end{array}$ & $2 \mathrm{p} 21$ & $\begin{array}{l}178 \\
(65.4)\end{array}$ & $\begin{array}{l}85 \\
(31.3)\end{array}$ & $\begin{array}{l}9 \\
(3.3)\end{array}$ & $\begin{array}{l}\text { 1- Thr } \\
\text { 2- Lys }\end{array}$ & $\begin{array}{l}441(81.1 \%) \\
103(18.9 \%)\end{array}$ \\
\hline $\begin{array}{l}\text { ABCG8 } \\
\text { Ala632Val }\end{array}$ & $2 \mathrm{p} 21$ & $\begin{array}{l}24 \\
(8.4)\end{array}$ & $\begin{array}{l}96 \\
(33.7)\end{array}$ & $\begin{array}{l}165 \\
(57.9)\end{array}$ & $\begin{array}{l}\text { 1- Ala } \\
2 \text { - Val }\end{array}$ & $\begin{array}{l}144(25.3 \%) \\
426(74.7 \%)\end{array}$ \\
\hline $\begin{array}{l}\text { ABCG5 } \\
\text { Gln604Glu }\end{array}$ & $2 \mathrm{p} 21$ & $\begin{array}{l}200 \\
(70.0)\end{array}$ & $\begin{array}{l}77 \\
(27.0)\end{array}$ & $\begin{array}{l}8 \\
(2.8)\end{array}$ & $\begin{array}{l}\text { 1- Glu } \\
2-\text { Gln }\end{array}$ & $\begin{array}{r}477(83.7 \%) \\
93(16.3 \%)\end{array}$ \\
\hline $\begin{array}{l}\text { APO B } \\
\text { I/D }\end{array}$ & $2 \mathrm{p} 24$ & $\begin{array}{l}138 \\
(48.9)\end{array}$ & $\begin{array}{l}108 \\
(38.3)\end{array}$ & $\begin{array}{l}36 \\
(12.8)\end{array}$ & $\begin{array}{l}1-\mathrm{I} \\
2-\mathrm{D}\end{array}$ & $\begin{array}{l}384(68.1 \%) \\
180(31.9 \%)\end{array}$ \\
\hline $\begin{array}{l}\text { APO CI } \\
D / I\end{array}$ & $19 q 13.2$ & $\begin{array}{l}192 \\
(67.6)\end{array}$ & $\begin{array}{l}85 \\
(29.9)\end{array}$ & $\begin{array}{l}7 \\
(2.5)\end{array}$ & $\begin{array}{l}1-D \\
2-I\end{array}$ & $\begin{array}{r}469(83.1 \%) \\
99(16.2 \%)\end{array}$ \\
\hline $\begin{array}{l}\text { APOE } \\
\text { e2/e3/e4 }\end{array}$ & $19 q 13.2$ & $\begin{array}{l}3 / 2 \\
2 / 2\end{array}$ & $\begin{array}{l}3 / 3 \\
4 / 2\end{array}$ & $\begin{array}{l}4 / 3 \\
4 / 4\end{array}$ & $\begin{array}{l}11-+\mathrm{e} 2 \\
12-\mathrm{e} 3 / 3 \\
22-+\mathrm{e} 4\end{array}$ & $\begin{aligned} 25 & (8.9 \%) \\
233 & (82.5 \%) \\
27 & (9.5 \%)\end{aligned}$ \\
\hline $\begin{array}{l}\text { APOCIII } \\
\text { C-482T }\end{array}$ & $11 q 23$ & $\begin{array}{l}120 \\
(43.5)\end{array}$ & $\begin{array}{l}125 \\
(45.3)\end{array}$ & $\begin{array}{l}31 \\
(11.2)\end{array}$ & $\begin{array}{l}1-\mathrm{C} \\
2-\mathrm{T}\end{array}$ & $\begin{array}{l}365(66.1 \%) \\
187(33.9 \%)\end{array}$ \\
\hline $\begin{array}{l}\text { APOCIII } \\
\text { C3238G }\end{array}$ & $11 q 23$ & $\begin{array}{l}216 \\
(76.9)\end{array}$ & $\begin{array}{l}61 \\
(21.7)\end{array}$ & $\begin{array}{l}4 \\
(1.4)\end{array}$ & $\begin{array}{l}1-C \\
2-G\end{array}$ & $\begin{array}{r}493(87.9 \%) \\
69(12.1 \%)\end{array}$ \\
\hline $\begin{array}{l}\text { LBP } \\
\text { Cys98Gly }\end{array}$ & $20 q 11.23-q 12$ & $\begin{array}{l}208 \\
(73.2)\end{array}$ & $\begin{array}{l}71 \\
(25.0)\end{array}$ & $\begin{array}{l}5 \\
(1.8)\end{array}$ & $\begin{array}{l}1 \text { - Cys } \\
2 \text { - Gly }\end{array}$ & $\begin{array}{r}487(85.7 \%) \\
81(14.3 \%)\end{array}$ \\
\hline $\begin{array}{l}\text { LBP } \\
\text { Leu436Pro }\end{array}$ & $20 q 11.23-q 12$ & $\begin{array}{l}1 \\
(0.3)\end{array}$ & $\begin{array}{l}52 \\
(18.7)\end{array}$ & $\begin{array}{l}225 \\
(81.0)\end{array}$ & $\begin{array}{l}1 \text { - Leu } \\
2 \text { - Pro }\end{array}$ & $\begin{array}{c}54(9.3 \%) \\
502(90.7 \%)\end{array}$ \\
\hline $\begin{array}{l}\text { BPI } \\
\text { Lys2 16Glu }\end{array}$ & $20 q 11.23-q 12$ & $\begin{array}{l}57 \\
(20.1)\end{array}$ & $\begin{array}{l}159 \\
(56.0)\end{array}$ & $\begin{array}{l}68 \\
(23.9)\end{array}$ & $\begin{array}{l}1 \text { - Lys } \\
2 \text { - Glu }\end{array}$ & $\begin{array}{l}273(48.1 \%) \\
295(51.9 \%)\end{array}$ \\
\hline $\begin{array}{l}\text { BPI } \\
\text { G545C }\end{array}$ & $20 q 11.23-q 12$ & $\begin{array}{l}204 \\
(71.8)\end{array}$ & $\begin{array}{l}78 \\
(27.5)\end{array}$ & $\begin{array}{l}2 \\
(0.7)\end{array}$ & $\begin{array}{l}1-G \\
2-C\end{array}$ & $\begin{array}{r}486(85.6 \%) \\
82(14.4 \%)\end{array}$ \\
\hline $\begin{array}{l}\text { BPI } \\
\text { PstI in intron } 5\end{array}$ & $20 q 11.23-q 12$ & $\begin{array}{l}97 \\
(34.0)\end{array}$ & $\begin{array}{l}132 \\
(46.3)\end{array}$ & $\begin{array}{l}56 \\
(19.7)\end{array}$ & $\begin{array}{l}1-\mathrm{T} \\
2-\mathrm{C}\end{array}$ & $\begin{array}{l}326(57.2 \%) \\
244(42.8 \%)\end{array}$ \\
\hline $\begin{array}{l}\text { TGF } \beta-1 \\
\text { Leu 10Pro }\end{array}$ & $19 q 13.1$ & $\begin{array}{l}96 \\
(35.8)\end{array}$ & $\begin{array}{l}141 \\
(52.6)\end{array}$ & $\begin{array}{l}31 \\
(11.6)\end{array}$ & $\begin{array}{l}1 \text { - Leu } \\
2 \text { - Pro }\end{array}$ & $\begin{array}{l}333(62.1 \%) \\
203(37.9 \%)\end{array}$ \\
\hline $\begin{array}{l}\text { TGF } \beta-1 \\
\text { Pro25Arg }\end{array}$ & $19 q 13.1$ & $\begin{array}{l}1 \\
(0.4)\end{array}$ & $\begin{array}{l}38 \\
(14.2)\end{array}$ & $\begin{array}{l}229 \\
(85.4)\end{array}$ & $\begin{array}{l}1 \text { - Pro } \\
2 \text { - Arg }\end{array}$ & $\begin{array}{c}40(7.5 \%) \\
496(92.5 \%)\end{array}$ \\
\hline $\begin{array}{l}\text { CD } 14 \\
\text { C-159T }\end{array}$ & $5 q 31.1$ & $\begin{array}{l}53 \\
(18.7)\end{array}$ & $\begin{array}{l}133 \\
(46.8)\end{array}$ & $\begin{array}{l}98 \\
(34.5)\end{array}$ & $\begin{array}{l}1-\mathrm{T} \\
2-\mathrm{C}\end{array}$ & $\begin{array}{l}239(42.1 \%) \\
329(57.9 \%)\end{array}$ \\
\hline $\begin{array}{l}\mathrm{ACE} \\
\mathrm{I} / \mathrm{D}\end{array}$ & $17 q 23$ & $\begin{array}{l}69 \\
(24.4)\end{array}$ & $\begin{array}{l}145 \\
(50.9)\end{array}$ & $\begin{array}{l}71 \\
(24.7)\end{array}$ & $\begin{array}{l}1-\mathrm{I} \\
2-\mathrm{D}\end{array}$ & $\begin{array}{l}283(49.6 \%) \\
287(50.4 \%)\end{array}$ \\
\hline $\begin{array}{l}\mathrm{HL} \\
\mathrm{C}-480 \mathrm{~T}\end{array}$ & $15 q 21-q 23$ & $\begin{array}{l}174 \\
(64.2)\end{array}$ & $\begin{array}{l}82 \\
(30.3)\end{array}$ & $\begin{array}{l}15 \\
(5.5)\end{array}$ & $\begin{array}{l}1-\mathrm{C} \\
2-\mathrm{T}\end{array}$ & $\begin{array}{l}430(79.3 \%) \\
112(20.7 \%)\end{array}$ \\
\hline $\begin{array}{l}\text { LPL } \\
\text { Ser447Stop }\end{array}$ & $8 p 22$ & $\begin{array}{l}227 \\
(81.7)\end{array}$ & $\begin{array}{l}50 \\
(18.0)\end{array}$ & $\begin{array}{l}1 \\
(0.3)\end{array}$ & $\begin{array}{l}1 \text { - Ser } \\
2 \text { - Stop }\end{array}$ & $\begin{array}{c}504(90.7 \%) \\
52(9.3 \%)\end{array}$ \\
\hline $\begin{array}{l}\text { CYP7A1 } \\
\text { A-204C }\end{array}$ & $8 q 11-q 12$ & $\begin{array}{l}67 \\
(25.5)\end{array}$ & $\begin{array}{l}140 \\
(53.2)\end{array}$ & $\begin{array}{l}56 \\
(21.3)\end{array}$ & $\begin{array}{l}1-\mathrm{A} \\
2-\mathrm{C}\end{array}$ & $\begin{array}{l}274(52.1 \%) \\
252(47.9 \%)\end{array}$ \\
\hline
\end{tabular}

ABC - ATP binding cassette, ACE - angiotensin converting enzyme, Apo - apolipoprotein, BPI - bactericidal/permeability increasing protein, CYP7A1 - cholesterol 7 alpha hydroxylase, D - deletion, I - insertion, HL - hepatic lipase, LBP - lipopolysaccharide binding protein, LPL - lipoprotein lipase, TGF - transforming growth factor. 
carriers of the rare allele, their data were pooled with heterozygotes and analyzed together. All analyses were performed separately for males and females and examinations were adjusted for smoking status.

\section{RESULTS}

Basic characteristics of the population sample are summarized in Table I. The plasma levels of thiocyanate were significantly higher $(p<0.01)$ in males $(106$ $\pm 54 \mu \mathrm{mol} / \mathrm{l})$ compared to females $(82 \pm 42 \mu \mathrm{mol} / \mathrm{l})$ and in smokers compared to non-smokers. This applied both to males $(132 \pm 48 \mu \mathrm{mol} / 1 \mathrm{vs} .90 \pm 59 \mu \mathrm{mol} / 1$, $p<0.01)$ and females $(134 \pm 45 \mu \mathrm{mol} / 1$ vs. $74 \pm$ $37 \mu \mathrm{mol} / 1, p<0.01$ ) (Table I). These significant associations were not influenced by the fact that there are more smokers among males and that the males smoked more cigarettes than females. Interestingly, smokers (but not non-smokers) have the same plasma levels of thiocyanate regardless of sex. In female non-smokers, we sought to determine whether or not there is an effect of menopausal status on the plasma levels of thiocyanate. Premenopausal females $(n=102)$ had lower plasma levels of thiocyanate than postmenopausal females $(n=52)$ $(68 \pm 28 \mu \mathrm{mol} / 1 \mathrm{vs} .82 \pm 36 \mu \mathrm{mol} / \mathrm{l})$, but the difference did not reach statistical significance.

The population genotype distribution patterns are summarized in Table II. Genotype frequencies did not differ between females and males, and these data are not included in the table.

None of the genetic variants analyzed was associated with smoking status, and/or the number of cigarettes smoked per week either in males or females.

We detected associations between SNPs at positions 11q23 (APOCIII, C-482T, $p<0.05$ ) and 19q13.1 (TGF $\beta-1$, Pro25Arg, $p<0.01$ ) on the one hand, and the plasma levels of thiocyanate on the other

\section{Table III}

Association between 11q23 (APOCIII) and 19q13.1

(TGF $\beta$ - 1 ) variants and plasma levels of thiocyanate

in males and females (values are given as mean $\pm \mathrm{SD}$, thiocyanate is in $\mu \mathrm{mol} / \mathrm{l})$.

\begin{tabular}{llrcc}
\hline \hline & & $1 / 1 \pm 1 / 2$ & $2 / 2$ & $p$ \\
\hline $19 q 13.1$ & Males & $110 \pm 52$ & $90 \pm 39$ & 0.01 \\
(TGF $3-1)$ & Females & $84 \pm 45$ & $65 \pm 22$ & 0.01 \\
$11 q 23$ & Males & $109 \pm 51$ & $78 \pm 28$ & 0.05 \\
(APOCIII) & Females & $83 \pm 44$ & $61 \pm 25$ & 0.05 \\
\hline \hline
\end{tabular}

(Table III). Associations were found in males as well as in females regardless of the fact that males showed a higher prevalence of smoking and higher plasma levels of thiocyanate compared with females. These associations were not influenced by smoking status.

Other variants showed no effect on the plasma levels of thiocyanate in males or females.

\section{DISCUSSION}

Our population study has confirmed that smokers have higher plasma levels of thiocyanate and that this association applies to males as well as females, although females show lower plasma levels of thiocyanate compared to males if only non-smokers are compared. However, the number of smokers in our study was not sufficient, and the number of cigarettes smoked per week varied largely (from 7 to 210 in males and from 7 to 175 in females), making us unable to confirm an expected association between the numbers of cigarettes smoked per week and the plasma levels of thiocyanate.

Our study is the first to date examining the question of genetic determination of the plasma levels of thiocyanate. We evaluated 23 randomly selected polymorphisms distributed unequally on eight chromosomes. Although our analysis was not representative for all sections on all chromosomes, we did succeed in identifying an association between the plasma levels of thiocyanate and genetic markers at positions 11q23 and 19q13.1. To lower the chance of false positive results, we performed the analysis separately in males and females. The possibility of obtaining false positive results simultaneously for males and for females for the same variant was only about $0.25 \%$.

We do not expect that variants per se in the genes for apolipoproteins, cell surface receptors, enzymes, transporters or cytokines could directly affect the plasma levels of thiocyanate. It is unlikely that they could influence some catabolic pathway of thiocyanate or have an effect on its absorption. It is more likely that other functional genes, not identified to date, are located at the same positions. Variants within these genes could be in allelic associations (linkage disequilibrium $=$ allelic association, a condition, whereby alleles of different genetic polymorphisms are connected predominantly in some combinations - in the case of relatively common $90 \%-100 \%$ association, it is necessary to analyze just one of the all associated variants) with the variants we have analyzed. These unknown genes could be involved, e. g., in thiocyanate transport or metabolism, or in the process of lung absorption of cyanate from tobacco smoke.

We found genetic markers affecting the plasma levels of thiocyanate both in males and in females at two positions, 19q13.1 (TGF $\beta-1$, Pro25Arg variant) and $11 \mathrm{q} 23$ (APOCIII, C-482T variant). These minimize the possibility that our results are false positive, because the associations were found in two independent associations.

Based on our results we can conclude that genetic determination of the plasma levels of thiocyanate is not a question of one variant in one gene, but results from the combined effect of many variants in several genes. Identification of these variants will warrant a number of detailed association studies.

In a representative selected Czech population sample, two genetic variants (at positions 11q23 and 19q13.1) play a role in genetic determination of the plasma levels of thiocyanate. Our results suggest that the plasma levels of thiocyanate are not a genetically independent marker of smoking/non-smoking status. Additional association studies are necessary for a more detailed analysis of genetic determination of the plasma levels of thiocyanate. 


\section{REFERENCES}

1. Molarius A, Parsons RW, Dobson AJ, et al. Trends in cigarette smoking in 36 populations from the early 1980s to the mid-1990s: findings from the WHO MONICA Project. Am J Public Health 2001;91:206-12.

2. Borges D, Junge B. Thiocyanate as an indicator of tobacco smoking. Preventive Medicine 1979;3:351-7.

3. Multinational monitoring of trends and determinants in cardiovascular diseases: "MONICA Project". Manual of operations WHO/MNC 82.2, Nov 1983.

4. Miller SA, Dykes DD, Polesky HF. A simple salting out procedure for extraction DNA from human nucleated cells. Nucl Acids Res 1988;16:1215.

5. Hixson JE, Vernier DT. Restriction isotyping of human apolipoprotein $\mathrm{E}$ by gene amplification and cleavage with HhaI. J Lipid Res 1990;31:545-48.

6. Waterworth DM, Hubacek JA, Kovar J, et al. The plasma levels of remnant particles are determined in part by variation in the apoCIII gene insulin response element and the apoCI-apoE cluster. J Lipid Res 2000; 41:1103-9.

7. Boerwinkle E, Chan L. A three codon insertion/deletion polymorphism in the signal peptide region of the human apolipoprotein B (apo B) gene directly typed by the polymerase chain reaction. Nucl Acids Res 1990; 17:4003.

8. Hubacek JA, Lacha J. Alternative method for diagnosis of two polymorphisms in the human transforming growth factor- $\beta 1$ by PCR-mediated double site-directed mutagenesis. Clin Chim Acta 2000;295:187-91.

9. Hubacek JA, Waterworth DM, Pitha J, et al. Polymorphisms in the lipoprotein lipase and hepatic lipase genes and plasma lipid values in Czech population. Physiol Res 2000;50:345-51.

10. Hubacek JA, Stueber F, Froehlich D, et al. Gene variants of the bactericidal/permeability increasing protein and lipopolysaccharide binding protein in sepsis patients - gender-specific genetic predisposition to sepsis. Crit Care Med 2001;29:557-61.

11. Hubacek JA, Berge KE, Štefková J, et al. Polymorphisms in ABCG5 and ABCG8 transporters and plasma cholesterol levels. Physiol Res 2004;53:395-401.

12. Wang J, Freeman DJ, Grundy SM, et al. Linkage between cholesterol 7a-hydroxylase and high plasma low-density lipoprotein cholesterol concentrations. J Clin Invest 1998;101:1283-91.

13. Hubacek JA, Rothe G, Pitha J, et al. C(-260) $\rightarrow$ T polymorphism in the promoter of the CD14 monocyte receptor gene as a risk factor for myocardial infarction. Circulation 1999;99:3218-20.

14. Rigat B, Hubert C, Corvol P, Subrier F. PCR detection of the insertion/deletion polymorphism of the human angiotensin converting enzyme gene (DCP1) (dipeptidyl carboxypeptidase 1). Nucl Acids Res 1993;20:1433.

15. Yoshida H, Kuriyama S, Atsumi Y, et al. Angiotensin I converting enzyme gene polymorphism in non-insulin dependent diabetes mellitus. Kidney Int 1996;50: 657-64.

16. Day IN, Humphries SE. Electrophoresis for genotyping: microtiter array diagonal gel electrophoresis on horizontal polyacrylamide gels, hydrolink, or agarose. Anal Biochem 1994;222:389-95.

Received 4 February 2006

Revision accepted 2 May 2006 